\title{
A PROTOCOL FOR EFFICIENT TRANSFORMATION AND REGENERATION OF CARICA PAPAYA L. ${ }^{3}$
}

\author{
WENQI CAI, CAROL GONSALVES, ${ }^{2}$ PAULA TENNANT, GUSTAVO FERMIN, MANOEL SOUZA, JR., NONGLAK SARINDU, \\ FUH-JYH JAN, HAI-YING ZHU, AND DENNIS GONSALVES
}

Department of Plant Pathology. Cornell University, Geneva, New York 14456

(Received 16 April 1998; accepted 28 October 1998; editor D. T. Tomes)

\begin{abstract}
SUMMARY
A reproducible and effective biolistic method for transforming papaya (Carica papaya L.) was developed with a transformation-regeneration system that targeted a thin layer of embryogenic tissue. The key factors in this protocol included: 1) spreading of young somatic embryo tissue that arose directly from excised immature zygotic embryos, followed by another spreading of the actively growing embryogenic tissue $3 \mathrm{~d}$ before biolistic transformation; 2) removal of kanamycin selection from all subsequent steps after kanamycin-resistant clusters were first isolated from induction media containing kanamycin; 3) transfer of embryos with finger-like extensions to maturation medium; and 4) transferring explants from germination to the root development medium only after the explants had elongating root initials, had at least two green true leaves, and were about 0.5 to $1.0 \mathrm{~cm}$ tall. A total of 83 transgenic papaya lines expressing the nontranslatable coat protein gene of papaya ringspot virus (PRSV) were obtained from somatic embryo clusters that originated from 63 immature zygotic embryos. The transformation efficiency was very high: $100 \%$ of the bombarded plates produced transgenic plants. This also represents an average of 55 transgenic lines per gram fresh weight, or 1.3 transgenic lines per embryo cluster that was spread. We validated this procedure in our laboratory by visiting researchers who did four independent projects to transform seven papaya cultivars with coat protein gene constructs of PRSV strains from four different countries. The method is described in detail and should be useful for the routine transformation and regeneration of papaya.
\end{abstract}

Key words: biolistic; genetic engineering; papaya ringspot virus; somatic embryogenesis; tissue culture; coat protein.

\section{INTRODUCTION}

Papaya (Carica papaya L.) is a fast-growing herbaceous tree that continuously bears fruit starting at 8-10 mo. after being transplanted to the field (Yeh and Gonsalves, 1994). This valuable crop is grown commercially in many tropical and subtropical countries for local and international export markets. In 1993, over one million metric tons (MT) of papaya was produced in Brazil (1.75 million MT) and India (1.2 million MT), while other countries such as Nigeria (500 $000 \mathrm{MT})$, Zaire (210 $000 \mathrm{MT})$, Mexico (343000 MT), and China (125000 MT) were also large producers (Galinsky, 1996). In the United States, Hawaii is the largest producer of papaya with 26000 MT (Galinsky, 1996). Papaya is also popularly grown in home gardens or scattered among other crops in small family farm plots. It is a good source of vitamins A and C (Arriola et al., 1980) and is especially important for subsistence farmers with limited resources. Ripe papaya is enjoyed the world over as a breakfast fruit, snack, or dessert. Green papaya is also used as a vegetable in dishes such as stew, curry, and soup.

Papaya ringspot is a major disease of papaya in Hawaii, Florida, and the countries of the Caribbean, South America, India, and the

${ }^{1}$ Based in part on a presentation at the 1997 SIVB Congress on In Vitro Biology held in Washington, DC, June 14-18, 1997.

${ }^{2}$ To whom correspondence should be addressed. E-mail: cvgl@nysaes cornell.edu.
Far East (Yeh and Gonsalves, 1994). Leaves of infected trees become mottled and distorted, ringspots appear on fruit, water-soaked streaks appear on stems and petioles and the plant becomes stunted, producing small fruit (Gonsalves, 1994). The disease is caused by papaya ringspot virus type $\mathrm{p}$ (PRSV-p), an aphid-transmissible potyvirus (Shukla et al., 1994). The host range of PRSV-p is confined to papaya and cucurbits, whereas the w type of PRSV infects cucurbits but not papaya (Purcifull et al., 1984). Classical breeding of commercial cultivars for PRSV-p resistance has not been successful because resistance in C. papaya $\mathrm{L}$. has not been found. Although resistance to PRSV-p is found in wild relatives such as $C$. cauliflora, their genes have not been successfully used because crosses between C. cauliftora and C. papaya are not fertile (Manshardt and Wenslaff, 1989).

The concept of parasite-derived resistance (Sanford and Johnston. 1985) has been highly successful for developing virus-resistant plants (Lomonossoff, 1995). A major breakthrough in controlling PRSV-p occurred with the development of transgenic papaya (Fitch et al., 1992) expressing the coat protein gene of PRSV HA 5-1, a mild nitrous acid mutant (Yeh and Gonsalves, 1984) of PRSV HA which was first isolated from Hawaii (Gonsalves and Ishii, 1980). R0 clones of a transgenic line "55-1," were highly resistant to PRSV HA in greenhouse experiments (Fitch et. al., 1992). Field experiments also showed that $\mathrm{R} 0$ and $\mathrm{R} 1$ plants were highly resistant under severe disease pressure in Hawaii (Ferreira et al., 1997; Lius et al., 1997). Two commercial cultivars (SunUp and UH Rainbow) were 
developed from line 55-1 (Manshardt, 1998). These will be very important in controlling PRSV in Hawaii, where the disease is causing extensive damage to the papaya crop (Gonsalves, 1998).

Interestingly, greenhouse experiments showed that hemizygous plants of line 55-1 are highly resistant to PRSV isolates from Hawaii but are susceptible to a number of PRSV isolates from other geographic regions (Tennant et al., 1994). This specificity of protection afforded by the hemizygous plants and the necessity of developing papaya with different horticultural characteristics have prompted our laboratory to develop more transgenic plants. Other laboratories have also regenerated transgenic papaya plants expressing the PRSV-p coat protein gene via Agrobacterium-mediated transformation from in vitro-generated petioles (Yang et al., 1996), and from somatic embryos derived from immature zygotic embryos (Cheng et al., 1996). It was recently demonstrated that the papaya lines derived from somatic embryos show resistance to PRSV isolates (Yeh et al., 1997). In addition, papaya transformation via the biolistic process has been used to produce transgenic plants expressing marker genes such as GUS and NPTII (Mahon et al., 1996), or to obtain aluminum tolerance (Fuente et al.. 1997).

A goal of our laboratory is to control PRSV-p worldwide through technology transfer and development of transgenic papaya with genes from PRSV-p isolates from different countries. Our initial efforts to do this were marginally successful, primarily because the transformation protocol we had previously used (Fitch et al., 1990) was not efficient for developing transgenic plants on a consistent basis. We thus worked toward optimizing the transformation method so that it would be reproducible. This report provides a detailed modified protocol that has been successfully used by a number of different personnel in our laboratory to transform embryogenic callus using the biolistic process.

\section{Materials and Methods}

Plasmid pGA482GG/untranslatable cpPRSV-pHA5-1.10. A plasmid containing the untranslatable coat protein (CP) gene of PRSV HA 5-1 (Gonsalves and Ishii, 1980; Yeh et al., 1992) was constructed for bombardment of embryogenic callus. DNA (100 ng) of pUCl8cpexp/cpPRSV-pHA5-1.85 (Tennant, 1996) served as a template in PCR reactions with a sense $5^{\prime}$ primer (UJLS9410 5'-ATCATTCCATGGCTGTGTGATGCTGGTTTG) that generated an inframe shift after the third amino acid of the CP gene and an antisense primer (DJLS86 5'-AGCTAACCATGGGGTGAAACAGGGTCG) complementary to $\mathrm{CP}$ sequences 27 base pairs downstream of the PRSV-p translation stop codon. After Taq DNA polymerase reaction, the resulting $1-\mathrm{kb}$ fragment was eluted from a low melting point agarose gel, digested with $N$ coI, and ligated to the vectors pGMM (Yepes et al., 1996) and pUC18cpexp (Slightom, 1991). The expression cassette was then excised from the recombinant pUC 18cpexp with HindIII and inserted into the binary vector pGA482GG (Quemada et al., 1990). In vitro translation experiments showed that the $\mathrm{CP}$ was not produced (Tennant, 1996). Plasmid DNA was isolated by banding in an ethidium bromide $\mathrm{CsCl}$ gradient (Ausubel et al., 1995). DNA was precipitated with ethanol, centrifuged at $7000 \mathrm{rpm}$ for $20 \mathrm{~min}$. and vacuum dried. The DNA was suspended in distilled water.

Microprojectile bombardment. Protocols described by Sanford et al. (1992) were used as a basis to set up experimental parameters, operate the heliumdriven particle accelerator, and prepare microprojectiles for bombardment. Sixty milligrams of tungsten particles (M-10; Sylvania, Towanda, PA) were sterilized in $1 \mathrm{ml}$ of $70 \%$ ethanol by vortexing for a few sec and soaking for 15 min or overnight. Then the particle mixture was centrifuged at high speed for $5 \mathrm{~min}$ (or until the supernatant was clear) and the supernatant was discarded. Particles were washed three times by vortexing in $1 \mathrm{ml}$ sterile distilled water, centrifuging, and removing the substrate each time. One milliliter of $50 \%$ glycerol was added to the tube. Fifty microliters of tungsten-glycerol suspension was loaded into sterile 1.5-ml Tekmar microtubes. To prepare six bombardments per tube, $5 \mu \mathrm{l}$ of DNA (at $2.5 \mu \mathrm{g} / \mu \mathrm{l}$ concentration), $50 \mu \mathrm{l}$ sterile $2.5 \mathrm{M} \mathrm{CaCl}_{2}$, and $20 \mu \mathrm{l}$ sterile $0.1 \mathrm{M}$ spermidine were quickly added to each tube, pipetted several times, and vortexed for 5 sec after earh addition.

Tubes were shaken 5 to $10 \mathrm{~min}$ on a platform shaker and. pulse-centrifuged about 6 sec; the supernatant was discarded. Coated particles were washed with $80-100 \mu \mathrm{l}$ of $70 \%$ ethanol and pulse-centrifuged. The supernatant was removed and $24 \mu \mathrm{l}$ of $100 \%$ ethanol was added. The tube was finger vortexed to suspend the particles. Three microliters of the DNA-coated particle suspension was loaded onto the center of sterile macrocarrier discs (Kapton membranes; DuPont, Wilmington, DE) that had been fitted onto brass rings. The rings with loaded discs were kept in petri plates with Drierite for $15 \mathrm{~min}$ before use.

Somatic embryo callus that had been spread on filter paper as described below was bombarded. The bombardment pressure, set at 1400 to $1500 \mathrm{psi}$, delivered the macrocarrier disc over a $1-\mathrm{cm}$ distance before striking a stopping screen which propelled the DNA-coated microprojectiles $12.3 \mathrm{~cm}$ to bombard the thin layer of embryogenic tissue. We shot each plate three times, moving the plate one-third turn each time.

Plant material and preparation for bombardment. This protocol is a modification of that described by Fitch et al. (1990). Green fruit of open pollinated "Sunrise" papaya, harvested 90 to $120 \mathrm{~d}$ after fruit set. was obtained from Hawaii. Each fruit was soaked for $1 \mathrm{~h}$ in $20 \%$ Clorox (1.05\% sodium hypochlorite) containing two drops of Tween 20 per liter of solution. Plump. white, immature seeds (Fig. $\perp A$ ) were transferred to sterile petri dishes for easy access and were stored in the refrigerator at $4^{\circ} \mathrm{C}$ or at room temperature (approximately $26^{\circ} \mathrm{C}$ ) until all embryos were extracted. Immature zygotic embryos (Fig. $l B$ ) were extracted from the seeds by our cutting away either end of the seed, then applying pressure to the longitudinal sides of the seed by squeezing with a forceps, to release the immature zygotic embryo. The embryos were placed on induction medium that was the same as that reported by Fitch et. al., (1990) except it contained carbenicillin. The medium consisted of half-strength Murashige and Skoog salts (Murashige and Skoog, 1962). $400 \mathrm{mg}$ L-glutamine per L, $50 \mathrm{mg}$ myo-inositol per L, $0.4 \mathrm{mg}$ thiamineHCl per L, $2 \mathrm{mg}$ glycine per L, $0.5 \mathrm{mg}$ nicotinic acid per L, $0.5 \mathrm{mg}$ pyridoxineHCl per L, 6\% sucrose, $10 \mathrm{mg}(45.25 \mu M)$ 2,4-dichlorophenoxyacetic acid (2,4-D) per L, and 0.8\% Difco Bacto-Agar, pH 5.8. Carbenicillin at $250 \mathrm{mg} /$ $\mathrm{L}$ was added to this and all media described herein, to minimize contaminations.

Ten immature zygotic embryos were arranged vertically in each $100 \times$ 15-mm petri plate. with their radicles immersed in the medium. Plates were kept in the dark at $28^{\circ} \mathrm{C}$. After 4 to 5 wk, ivory-colored somatic embryo clusters about $2-3 \mathrm{~mm}$ in diameter (Fig. 1 C) had developed at the apical dome of the zygotic embryos. Seven zygotic embryos with their somatic embryo clusters were placed on Whatman \#2 filter paper (which was overlaid on fresh induction medium) and firmly spread over the filter paper with a spatula. Most of the embryos were squashed and spread during this process. The somatic embryo tissues were allowed to proliferate for another 4 to $5 \mathrm{wk}$ (Fig. $1 D$ ). Subsequently, in preparation for bombardment, the embryos were again spread firmly (Fig. $1 E$ ) onto fresh filter paper on induction medium with 1\% Difco Bacto Agar and bombarded with DNA-coated tungsten particles 3 d later. Twelve plates were bombarded with plasmids containing the untranslatable coat protein gene of PRSV-p HA 5-1 (prepared as described above); 12 control plates were bombarded only with microprojectiles and another three plates were not bombarded. After bombardment all plates were transferred to the dark at $28^{\circ} \mathrm{C}$.

Plant regeneration and rooting. Seven $\mathrm{d}$ after bombardment, all of the DNA-bombarded and half of the control materials were transferred to induction medium containing kanamycin at $75 \mathrm{mg} / \mathrm{L}$. The other control plates were kept on induction medium without kanamycin to help facilitate comparisons between the development of control tissues (both with and without kanamycin selection) and tissues bombarded with DNA. During this and subsequent transfers to induction medium with kanamycin. we kept cultures undisturbed by moving them on the same filter paper on which they were bombarded. After $4 \mathrm{wk}$, the kanamycin level was raised to $150 \mathrm{mg} / \mathrm{L}$. Controls included both nonbombarded tissues and those bombarded without DNA. After another four or more wk on kanamycin at $150 \mathrm{mg} / \mathrm{L}$, independent, actively growing embryo clusters of 2 to $3 \mathrm{~mm}$ in diameter (Fig. $1 F$ ) were removed from the filter paper and transferred to kanamycin-free induction medium in separate petri dishes. Clusters were laid on the medium and were gently teased apart with a forceps to allow the upper somatic embryos to fall into contact with the medium. When embryos developed an ivory (pale yellow) color and appeared as finger-like extensions that had elongated to about $1.5 \mathrm{~mm}$ long (Fig. 

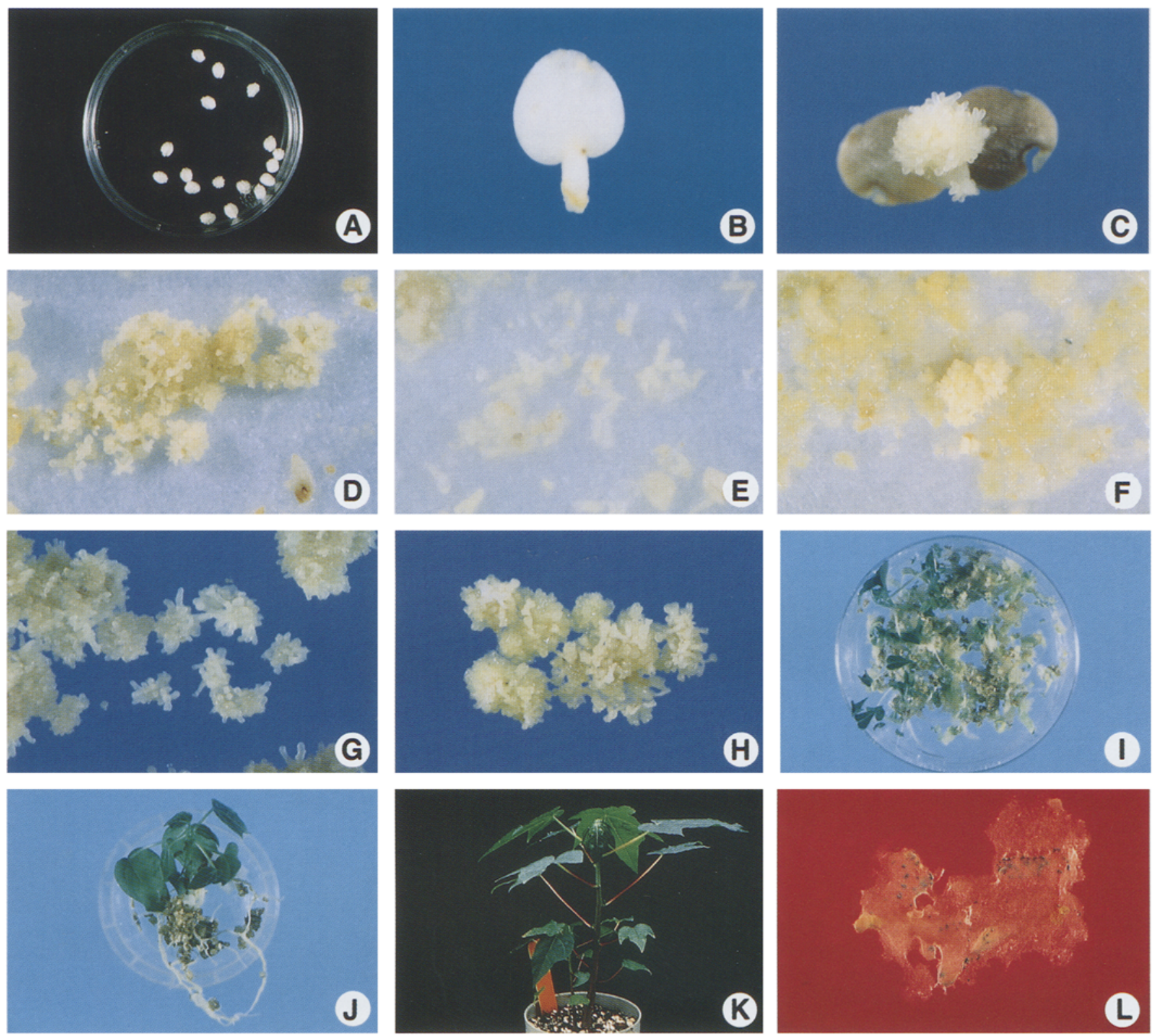

Fig. 1. 'Sunrise' solo papaya transformation and regeneration. $A$, Plump, white seeds from which embryos were excised. $B$, Immature zygotic embryos excised from seed. $C$, Ivory-colored somatic embryo cluster, produced from zygotic embryo after 4 to 5 wk on induction medium. $D$. Squashed embryogenic tissue cells were allowed to proliferate for 4 to 5 wk. $E$, Embryos ready for bombardment, $3 \mathrm{~d}$ after a second spreading on filter paper. $F$, Kanamycin-resistant embryo cluster. $G$, Pale-yellow embryo clusters with finger-like extensions in induction medium. $H$, Embryos enlarged and turned green in maturation medium. $I$. Plantlets in germination medium elongated and developed dark green leaves and roots. J. Plants developed an extensive root system after 3 to $4 \mathrm{wk}$ in vermiculite infused with an equal amount of germination medium. $K$. Plants were transferred to the greenhouse. $L$, Transient X-gluc assay of bombarded embryogenic plant tissue.

$1 G)$, they were transferred to maturation medium, which was identical to the induction medium described above except that it did not contain 2,4-D.

All embryos on induction medium were kept in the dark. Subsequently, cullures were kept under cool-white fluorescent light for a photoperiod of 16 $\mathrm{h}$ light at $25^{\circ} \mathrm{C}$ during the maturation, germination, and rooting steps. Somatic embryo cultures were kept in maturation medium from two to a maximum of four wk, allowing them to enlarge and turn green ( $\mathrm{Fig} .1 \mathrm{H}$ ). Mature somatic embryos were transferred to germination medium (Fitch, 1993) consisting of full-strength MS salts, $100 \mathrm{mg} m \gamma$-inositol per L, $0.4 \mathrm{mg}$ thiamine- $\mathrm{HCl}$ per L, $3 \%$ sucrose, and $0.8 \%$ Difco Bacto-Agar, pH 5.8. After 2 to 3 mo. (sub- cultured monthly) in this medium, somatic embryos developed into plantlets with root initials and dark green leaves (Fig. $1 l$ ). Some cultures continued to produce plantlets in germination medium for up to 16 mo.

Plantlets in germination medium that were 0.5 to $1.0 \mathrm{~cm}$ tall, had at least two green leaves, and had root initials (Fig. $1 I$ ) were transferred to baby food jars containing a mixture with equal volumes ( $35 \mathrm{ml}$ each) of Vermiculite autoclaved with liquid rooting medium (1/2 MS salts, $50 \mathrm{mg}$ myo-inositol per $\mathrm{L}, 0.2 \mathrm{mg}$ thiamine. $\mathrm{HCl}$ per $\mathrm{L}, 15 \mathrm{gm}$ sucrose) at $\mathrm{pH}$ 5.8. Plants developed extensive roots in 3 or $4 \mathrm{wk}$ ( $\mathrm{Fig}$. $1 \mathrm{~J}$ ). The tissue culture rooting mix was carefully rinsed off and plants were transferred to the greenhouse in 4-inch 
pots containing a mixture of 4 parts Cornell potting mix (Peters Fertilizer Products, W. R. Grace \& Co., Fogelsville, PA), 1 part Perlite, and 1 part Vermiculite. Pots were capped with clear plastic bags, and a wk later a comer of each bag was cut away and gradually cut fully open until the plant had become acclimatized to the greenhouse (Fig. $1 K$ ).

Analysis of plant material. Cultured material or plants were analyzed by $\mathrm{X}$-glue, NPTII ELISA (neomycin phosphotransferase II; enzyme-linked immunosorbent assay), polymerase chain reaction (PCR), or Southern blots. The histochemical GUS assay (Jefferson, 1987) using X-gluc (5-bromo-4-chloro3 -indoyl- $\beta$-glucuronidase) was done with a protocol by McCabe et al. (1988). We tested for transient GUS expression $7 \mathrm{~d}$ after bombardment by immersing randomly sampled, bombarded tissue in $\mathrm{X}$-gluc substrate overnight at $37^{\circ} \mathrm{C}$ and observing blue spots with a dissecting microscope (Fig. 1 L). A test for stable GUS expression was done on the same day that an embryo cluster was removed from induction medium with $150 \mathrm{mg}$ of kanamycin per $\mathrm{L}$ to kanamycin-free induction medium (beginning at about 2-3 mo. after bombardment). Embryos that showed a blue or dark blue reaction were deemed to be stably transformed.

After plants were established in the greenhouse, leaf tissues were tested by X-gluc for confirmation of previous results. Also, leaf tissues (10 to 15 $\mathrm{mg}$ ) from the youngest fully-expanded leaves were assayed by NPTII ELISA with a protocol from 5 Prime-3 Prime (Boulder, CO) to detect the NPTII protein in crude cellular leaf extracts. The CP gene of PRSV was detected by PCR with primers specific to CP. The $3^{\prime}$ end primer was: $5^{\prime}$-AGCTAACCATGGGGTGAAACAGGGTCG, and the $5^{\prime}$ end primer was: 5'-ATCATTCCATGGGCTCCAAGAATGAAGCTGTG. Southern blots were performed to confirm stable transformation and to determine the number of gene inserts in selected papaya plants. Plant genomic DNA was extracted as described by Razin (1988) BglII-digested DNA (12 $\mu \mathrm{g}$ per sample) were electrophoresed in $0.7 \%$ agarose gel and transferred by capillarity to GeneScreen Plus (NEN Products, Boston, MA) as described by Ausubel et al. (1995). Hybridization conditions followed the protocol for the GeneScreen Plus membrane with random priming methods to generate the ${ }^{32} \mathrm{p}$-labeled CP gene fragment. Autoradiography was done by exposing the membrane for $48 \mathrm{~h}$.

\section{RESULTS}

Zygotic embryo extraction. We used the 'Sunrise' cultivar for transformation because it is widely planted throughout the world and highly desired by commercial producers. Since all of the seeds in a fruit were at about the same developmental stage, two good fruits provided ample material for a number of experiments. Plump. white seeds (Fig. $1 \mathrm{~A}$ ) produced the best type of zygotic embryos (Fig. 1 $B$ ). Small white seeds had nearly transparent embryos and a milky fluid. These did not produce somatic embryo clusters. Older, black seeds and those with a light brown cast were not used because the seed coats were hard, and thus embryo extraction was difficult and time-consuming. Also, embryos from black seeds did not readily regenerate somatic embryos. Our criteria for optimal zygotic embryos were based on experience of extracting several thousand zygotic embryos from prior and concurrent experiments.

The zygotic embryo cotyledons opened within $7 \mathrm{~d}$ after transfer to induction medium, exposing the meristem where a cluster of somatic embryos, about 2-3 $\mathrm{mm}$ in diameter, developed in 4 to $5 \mathrm{wk}$ (Fig. 1 C). In an experiment in which 420 zygotic embryos were excised and observed, 43\% (181/420) of the zygotic embryos produced somatic embryos after 4 wk on induction medium.

Somatic embryo proliferation and spreading. Embryogenic clusters that contained a mixture of globular, heart, and torpedo stages of embryos developed 4-5 wk after zygotic embryos were placed on induction medium (Fig. $1 \mathrm{C}$ ). An average of seven of these clusters per petri plate were transferred to filter paper that was laid on top of induction medium. With a metal spatula, the clusters were spread firmly onto the filter paper. Younger embryogenic tissue, including a slimy yellow-brown substance, could be squashed or spread thinly, but mature embryos were harder and tended to stay intact. Numerous somatic embryos regenerated from this tissue within $4 \mathrm{wk}$, forming a loose layer of somatic embryos (Fig. $1 \mathrm{D}$ ), unlike the previous clusters of developing or early-stage embryos that were attached to the apical meristem. The newly formed embryos (at the globular and torpedo stages) resulted in an increased mass of tissue for bombardment. These and other cultures in the plate were respread on fresh medium and filter paper 4 wk after the first spreading, and were bombarded 3 d later (Fig. 1 E).

Selection of kanamycin resistant clusters. Cultures were kept in the bombarded petri dishes for $7 \mathrm{~d}$ to allow time for cells to recover and begin to grow. After this 7-d period, a small tissue sample from each plate was tested by X-gluc for transient GUS expression. Observation under a dissecting microscope revealed numerous blue foci (Fig. 1 $L$ ) in samples from nine DNA-bombarded plates. Another three plates that were bombarded had been eliminated from the experiment because they were contaminated. After testing, the embryogenic tissues remaining in the bombarded plates were transferred, undisturbed on their original filter papers, to selective induction medium containing Carbenicillin at $250 \mathrm{mg} / \mathrm{L}$ and kanamycin at $75 \mathrm{mg} / \mathrm{L}$. Four wk later, the kanamycin concentration was increased to 150 $\mathrm{mg} / \mathrm{L}$. The bombarded tissues (kept in place on their filter papers) were subcultured monthly.

In the bombarded plates, certain tissues seemed to be more sensitive to the increased level of kanamycin. Somatic embryos that were too old to be crushed during the spreading process still appeared healthy shortly after bombardment; however, they never grew larger in kanamycin selection and some of them turned brown. Also, some embryogenic tissues that initially developed pale yellow somatic embryos turned a chalky white, stopped growing, and eventually turned brown. Other embryogenic tissue did not develop at all and merely turned brown. In contrast, putative transformed embryos emerged as pale yellow clusters that grew out among the mass of brownish embryogenic tissues (Fig. $1 F$ ). When observed with a dissecting microscope, these somatic embryos were taut, glistening, and pale yellow. A light yellow-brown slimy fluid existed near the base of the embryos. Over a period of 3 to 9 mo. after bombardment, 207 independent kanamycin-resistant clusters were transferred from induction medium with kanamycin selection to induction medium without selection and kept on this nonselective medium for at least 1 mo. (Tables I and 2). Two-thirds (138/207) of the clusters were positive in X-gluc tests (Table 2).

Each kanamycin-resistant cluster was treated as an independent plant line. Therefore, when transferred to kanamycin-free induction medium for further development, the embryogenic clusters were kept in separate plates. The embryos were gently teased apart with a forceps to ensure full contact with the medium. Kanamycin selection was discontinued from this point on because sporadic initial growth of control tissue on kanamycin at $75 \mathrm{mg} / \mathrm{L}$ had ceased when followed by 1-2 mo. on induction medium with kanamycin at $150 \mathrm{mg} / \mathrm{L}$. Additionally, kanamycin was discontinued to avoid possible adverse effects on plant growth similar to those reported for apple and grape, in which low doses of kanamycin inhibited regeneration (Gray and Meredith, 1992; Yepes and Aldwinckle, 1994).

Control tissues that were not bombarded, or were bombarded without DNA either did not produce embryogenic clusters on induction medium with $75 \mathrm{mg}$ kanamycin per $\mathrm{L}$ or developed a limited number of embryos which turned necrotic when transferred to $150 \mathrm{mg}$ kanamycin per L. 
TABLE 1

TIMELINE FOR PRODUCTION OF TRANSGENIC 'SUNRISE' PAPAYA AFTER BOMBARDMENT

\begin{tabular}{|c|c|c|c|}
\hline \multirow[b]{2}{*}{ Production stage } & \multicolumn{2}{|c|}{ Month $8^{a}$} & \multirow[b]{2}{*}{ Average time } \\
\hline & First & Last & \\
\hline Total time on induction medium & 4 & 10 & 4 months \\
\hline Induction with kanamycin & 3 & 9 & \\
\hline $75 \mathrm{mg} / \mathrm{L}$ & & & 1 month \\
\hline $150 \mathrm{mg} / \mathrm{L}$ & & & $2-3$ months \\
\hline Induction without kanamycin & 4 & 10 & l-2 months \\
\hline Maturation & 4 & 11 & 2 to 3 weeks \\
\hline Germination & 5 & 21 & 3 months \\
\hline Root development & 8 & 22 & 3 to 4 weeks \\
\hline Green (establishment) & 9 & 25 & 3 to 4 weeks \\
\hline
\end{tabular}

a'The 'first' month refers to the earliest timepoint after bombardment at which events in a production stage were completed for this experiment. The 'last' column shows the latest month after bombardment at which tissue was kept at a particular stage. Germination, root development, and greenhouse stages were prolonged in order to obtain a large number of plants for testing in the greenhouse.

"Average time taken to complete each step.

Plant regeneration. We attempted to regenerate plants from all kanamycin-resistant clusters regardless of whether they were negative in the X-gluc test. Thus, a back-up portion of each cluster was subcultured on kanamycin-free medium where they continually developed globular, heart, and torpedo embryos in an asynchronous manner. Otherwise, when most of the pale yellow embryos in a cluster developed finger-like extensions (Fig. $1 G$ ), the cluster was transferred from the kanamycin-free medium to maturation medium and kept in the light. Here, the cultures both proliferated and turned green (Fig. 1 $H$ ). Although transfers of independent cell lines from induction to maturation medium were done over a period of $6 \mathrm{mo}$. (4 to 10 mo. after bombardment) (Table 1), 84\% (70/83) of the total transgenic plant lines were identified within the first 4 mo. During this period, 5 lines died, and 18 lines became contaminated, leaving 184 of the 207 original kanamycin-resistant lines in culture. Included in these 184 lines were the $138 \mathrm{X}$-gluc-positive lines, plus $48 \mathrm{X}$-gluc-negative lines which had not died or become contaminated (see details in legend of Table 2). After 2 to 4 wk on maturation medium, small plantlets had developed green cotyledons in $97 \%$ (178/184) of the independently selected embryogenic clusters. These cultures were transferred to germination medium for further development (Fig. 1 $H$ ).

Various structures were observed in the germination stage (Fig. 1 I). In one type, true leaves developed from clusters of leaf structures, followed by stem elongation and root development. In a second type, the hypocotyl elongated first and had a top of white leaf structures, which later developed true leaves. In a third type, green or white leafy structures developed from callus and later gave rise to true leaf development and plantlets.

Since independent embryo clusters had multiplied extensively on induction medium, 10 to 20 plates of embryos from each line were transferred to germination medium. Overall, plants from 99 of the 178 plant lines in germination medium were subsequently transferred to root development medium (Table 2). Over time, we found

TABLE 2

DEVELOPMENT ${ }^{a}$ AND TESTING ${ }^{b}$ OF 207 INDEPENDENTLY SELECTED KANAMYCIN-RESISTANT EMBRYOGENIC CLONES FROM 9 PLATES OF BOMBARDED SOMATIC EMBRYO CELLS

\begin{tabular}{|c|c|c|c|c|c|c|c|c|c|}
\hline \multirow[b]{2}{*}{ Plate no. } & \multicolumn{5}{|c|}{ Tissue Culture: Somatic embryo tissue } & \multicolumn{4}{|c|}{ Greenhouse: Leaf tissue } \\
\hline & Induction & $\mathrm{X}$-gluc ${ }^{*}$ & Maturation & Germination & Rooting & Greenhouse & $\mathrm{X}$-gluc ${ }^{\circ}+$ & NPTII '+’ & Transgenic \\
\hline $\mathrm{P} 2$ & 58 & $39 / 58$ & 53 & 53 & 32 & 23 & $13 / 23$ & $14 / 23$ & 22 \\
\hline P8 & 4 & $0 / 4$ & 4 & 4 & 1 & 1 & $0 / 1$ & $1 / 1$ & 1 \\
\hline P10 & 4 & $4 / 4$ & 3 & 3 & 3 & 3 & $3 / 3$ & $3 / 3$ & 3 \\
\hline P15 & 18 & $13 / 18$ & 15 & 15 & 6 & 6 & $4 / 6$ & $6 / 6$ & 6 \\
\hline $\mathrm{P} 22$ & 10 & $6 / 10$ & 8 & 6 & 3 & 3 & $2 / 3$ & $3 / 3$ & 3 \\
\hline P24 & 4 & $3 / 4$ & 2 & 2 & 1 & 1 & $1 / 1$ & $1 / 1$ & 1 \\
\hline P25 & 16 & $11 / 16$ & 13 & 12 & 7 & 5 & $4 / 5$ & $3 / 5$ & 5 \\
\hline P29 & 8 & $6 / 8$ & 8 & 8 & 3 & 3 & $2 / 3$ & $2 / 3$ & 3 \\
\hline P31 & 85 & $56 / 85$ & 78 & 75 & 43 & 41 & $30 / 41$ & $32 / 41$ & 39 \\
\hline Total clones & 207 & $138 / 207$ & 184 & 178 & 99 & 86 & $59 / 86$ & $65 / 86$ & 83 \\
\hline$\%$ of Total & 100 & 67 & 89 & 86 & 48 & 42 & 71 & 78 & 40 \\
\hline
\end{tabular}

anduction medium shows the number of individual kanamycin-resistant clones (independent events) selected after 3 or more months on kanamycin. Between the induction and maturation transfers, 5 lines died or had poor development and 18 became contaminated. In maturation medium, 1 line died and 5 became contaminated. In germination medium, 59 lines were lost to poor development, very small size, or cultures that turned white and died. Contamination of 20 lines occurred during the germination and rooting phases. Thirteen lines were lost due to poor growth in the greenhouse. Eighty-three of the 86 lines established in the greenhouse were transgenic (see definition above). Eight nonbombarded or bombarded (without DNA) controls germinated, and four of these lines were transferred to the greenhouse.

${ }^{b}$ Tissue culture X-gluc tests were done just before selected embryogenic clusters were moved to nonkanamycin containing induction medium. X-gluc and NPTII ELISA results show the ratio of the number of positive samples to the total number tested. Positive $X$-gluc readings were based on visual rating of the intensity of blue spots in bombarded tissue. Transgenic plants were positive by X-gluc and/or NPTII ELISA tests (except for one line which was negative in both tests, but positive in a PCR test). A reading for NPTII ELISA was considered positive if it was three or more times the average reading of the negative controls ( 4 wells per plate) and the sample showed visual color differences from the negative controls. The range of healthy ( - ) control plants in NPTII ELISA was 0.002 to 0.196 , and the range of positive readings was 0.172 to 1.435 .

'This study resulted in 83 independent 'Sunrise' papaya lines. 
TABLE 3

\section{FURTHER CHARACTERIZATION OF NINE TRANSGENIC 'SUNRISE' PAPAYA LINES}

\begin{tabular}{|c|c|c|c|c|c|}
\hline \multirow[b]{2}{*}{ Line no. } & \multirow{2}{*}{$\begin{array}{c}\begin{array}{c}\text { Tissue } \\
\text { culture: } \\
\text { Embryo- } \\
\text { genic tissue }\end{array} \\
\text { X-gluc }\end{array}$} & \multicolumn{4}{|c|}{$\begin{array}{l}\text { Greenhouse: } \\
\text { Leaf tissue }\end{array}$} \\
\hline & & $X$-gluc & NPTII/ELISA & PCR & $\begin{array}{c}\text { Southern blot/ } \\
\text { gene copies }\end{array}$ \\
\hline $\mathrm{P} 2 \# 13$ & ++ & - & - & + & 1 \\
\hline P2\#16 & ++++ & - or + & + & + & 3 \\
\hline P2\#19 & +++ & ++ or $t+t$ & + & + & 4 \\
\hline P2\#43 & ++++ & - or + & + & + & 5 \\
\hline $\mathrm{P} 10 \# 4$ & $+++t$ & $-t_{0}++$ & + & + & 2 \\
\hline P3l\#29 & $++t$ & - to ++++ & + & + & 6 \\
\hline P31\#31 & ++ & - to +++ & + & + & 6 \\
\hline P3l\#4l & ++ & - & + & + & 1 \\
\hline P31\#42 & ++ & - to + & + & + & 3 \\
\hline
\end{tabular}

"The naming of the papaya lines included the bombarded plate number (i.e., plates P2, P10, and P31) as well as the number of the independent embryogenic cluster which was designated when the cluster was removed kanamycin selection.

that three factors were important for ensuring reliable and consistent root development. The small plantlets had to be kept in germination medium until they had the following characteristics (Fig. $1 I$ ): 1) they were at least 0.5 to $1.0 \mathrm{~cm}$ tall, 2) they had at least two expanded green leaves, and 3) the roots had already begun to elongate. Such plantlets developed extensive root systems 3 to 4 wk after transfer to the vermiculite plus root development medium (Fig. $1 J$ ). The loss of 79 lines between the germination and rooting medium phases were due to poor or no growth and to contamination (see legend of Table 2).

Greenhouse growth. Eighty-six of the 99 plants that were transferred to the greenhouse developed into established plants (Fig. 1 $K)$. The remaining 13 plants had very poor growth and were subsequently discarded. Some plants were established in the greenhouse as early as 9 mo. after bombardment (Table 1). However, the first large group of plants ( $30 \%$ of the total) were transferred to soil 12 mo. after bombardment; and by the 13 th mo. after bombardment $82 \%$ of the plant lines had been potted (data not shown). Although 86 plant lines grew in the greenhouse, later tests showed that three of these were nontransgenic escapes (Table 2). A stock plant of every transgenic plant line was maintained for observation and for making vegetatively propagated clones which could be used in virus infectivity tests. The lengthy "last" mo. for "germination," "root development," and "greenhouse" (21, 22, and 25 mo, respectively) shown in Table 1 were due to our practice of storing a supply of plant lines in germination medium so that plantlets with developing roots could be sent to the greenhouse for further studies, as needed.

Transformation efficiency. A total of 207 kanamycin resistant clusters (ranging from 4 to 85 separate clusters per plate) were obtained from nine bombarded plates (Table 2). Of these, 83 independent transgenic lines were fully established in the greenhouse. Leaf tissues from greenhouse plants were tested by X-gluc and/or NPTII assays. Plants that were positive in at least one of these tests were considered to be transgenic. One line ( $\mathrm{P} 2 \# 13)$ which was negative in both tests was positive for the CP gene in a PCR test (Table 3). All of the bombarded plates (100\%) produced transgenic clones (Ta-
TABLE 4

\section{COMPARISON OF TRANSFORMATION EFFICIENCY OF PAPAYA WITH PRSV-P CP GENES FROM DIFFERENT CEOGRAPHIC REGIONS}

\begin{tabular}{llc}
\hline Origin of PRSV+. & Papaya cultivar & Transformation efficiency \\
\hline Hawaii & Sunrise & $100(9 / 9)$ \\
Brazil & Sunrise/Sunset & $78(61 / 98)$ \\
Jamaica & Sunrise & $83(10 / 12)$ \\
& Sunrise & $33(2 / 6)$ \\
Mexico & Sunrise & $33(40 / 118)$ \\
Thailand & Thapra 1 & $100(5 / 5)$ \\
& Thapra 2 & $100(6 / 6)$ \\
& Thapra 3 & $100(3 / 3)$ \\
& Kaekdum & $67(2 / 3)$ \\
& Kaeknuen & $97(30 / 31)$ \\
& Sunrise & $100(4 / 4)$ \\
\hline
\end{tabular}

aPRSV was propagated in Dennis Gonsalves' laboratory and the CP genes engineered as described in this work. The $\mathrm{CP}$ genes were in translatable or untranslatable forms.

'The following researchers repeated the protocols for transformation and regeneration of 'Sunrise' papaya (that were reported in this paper) using PRSV genes from geographical locations other than Hawaii: Manoel Souza (Brazil), Paula Tennant (Jamaica), Fuh-Jyh Jan and Hai-Ying Zhu (Mexico), and Nonglak Sarindu (Thailand).

"Transformation efficiency is based on the percentage of bombarded plates that produced transgenic embryogenic clusters. Each of the plates contained a layer of somatic embryo tissue that was obtained from seven zygotic embryos. Protocol used is described in Materials and Methods.

"Only the plates with clusters that were tested by NPTII ELISA are included in these data. Data are not given for plates with independent clones that were too small to be removed from kanamycin selection when these data were taken. Respective to the cultivars listed, the total number of bombarded plates were $19,16,19,7,73,28$.

bles 2,4). We defined the transformation efficiency in several other ways by comparing the number of transgenic plant lines obtained (83 lines) to the number of bombarded: 1) embryo clusters used for spreading $(83 / 63)=1.3$ lines per cluster, 2) grams of fresh tissue weight of clusters that were initially spread $(83 / 1.5$ grams $)=55$ lines per gram, and 3) plates $(83 / 9)=9$ lines (average) per plate.

Characterization of transgenic plants. Nine plant lines, selected at random from the first 21 plants transferred to the greenhouse, were further characterized by X-gluc, NPTII ELISA, PCR, and Southern blots (Table 3). Although the X-gluc data showed a tendency toward lower readings than those in tissue eulture, plants gave positive results in NPTII (for all but one line), PCR, and Southern blots (Table 3; Fig. 2, 3). The Southern blots revealed plants with one to six gene copies (Table 3; Fig. 3). Interestingly, line P2\#13 was negative in greenhouse tests for the GUS and NPTII genes, but the CP gene was detected in PCR and Southern blot tests (Table 3). Conversely, none of the plants that were positive for X-gluc or ELISA were negative in PCR or Southern assays (Table 3). Plants transferred from tissue culture to potting mix generally showed normal morphology (Fig. 1 $K)$. However, variation was seen in some plants, including fasciated stems, multiple shoots growing from a stem. and different leaf shapes (data not shown).

Transformation with other PRSV-CP transgenes. A number of concurrent and later experiments in our laboratory were done with the same transformation-regeneration protocols described herein, with results of transformation efficiency ranging from $100 \%$ to $33 \%$ (Table 4). The experiments used 'Sunrise', and Thailand cultivars 'Kae- 


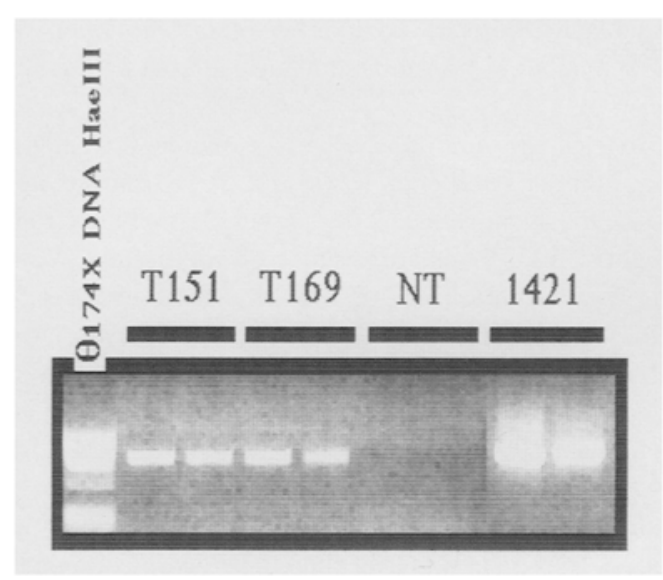

FIG. 2. PCR analysis of the PRSV coat protein gene in transgenic papaya plants. Total genomic DNA from transgenic plants T151 (P2-43), and T169 (P31-31), and from a nontransformed plant (NT). as well as a DNA construct (1421) used to transform papaya somatic embryos, were used as templates for PCR amplification of the CP gene. A PCR product of about 900 neucleotides was seen in all but the nontransformed plant.

knuen', 'Kaekdum”, 'Thapra 1', 'Thapra 2', and 'Thapra 3'. The gene constructs included the CP genes from PRSV-p strains from Brazil, Jamaica, Mexico, and Thailand (Table 4).

\section{Discussion}

The availability of an efficient and reproducible regeneration and transformation system is perhaps the most important step toward the development of transgenic plants. The transformation method detailed in this report is both efficient and reproducible. We obtained 83 transgenic papaya lines from nine bombarded plates of somatic embryos and the plants were fully established in the greenhouse. Furthermore, this transformation method has been successfully used in our laboratory by different primary investigators who used different genes and papaya cultivars to produce PRSV resistance to strains in Brazil, Jamaica, Mexico, and Thailand. The described transformation protocol should be applicable to many papaya cultivars because it has been successfully used for seven papaya cultivars reported here.

The protocol we have developed is an adaptation of the work by Fitch et al. (1990, 1992, 1993) who were the first to develop a transgenic papaya. The protocol was adapted because our efforts to repeat the published procedures did not give satisfactory results. Thus, the objectives of the experiments reported here were to use key aspects of the prior work and to add our own innovations in order to boost transformation efficiency.

Four key elements helped make this a highly efficient protocol. The first was the spreading of young somatic embryo tissue that arose directly from excised immature zygotic embryos. Previously, we used secondary embryos (initiated from zygotic embryos) that were continuously cultured on induction medium for up to $10 \mathrm{mo}$. This approach was not successful. In the protocol reported here zygotic embryos were excised and somatic embryo clusters that grew from their apical dome were spread twice before transformation. Our observations suggest that the method of spreading somatic embryos on filter paper before bombardment forced the embryos into a uniform stage of development in which cells were rapidly dividing. Regeneration was

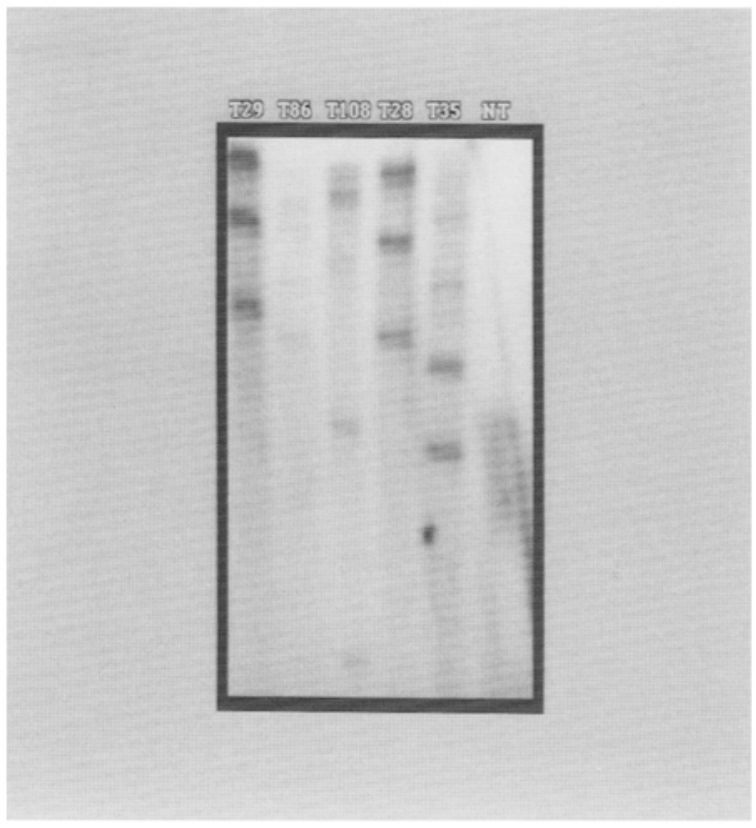

FIG. 3. Southern blot analysis of the PRSV coat protein gene in transgenic papaya plants. $B g l I I-d i g e s t e d$ genomic DNA $(12 \mu \mathrm{g})$ were separated in $0.7 \%$ agarose gel. blotted onto a nylon membrane, and probed with a ${ }^{32} \mathrm{P}$ labeled DNA fragment of the PRSV HA coat protein gene. T29 (P2-16), T86 (P2-24). T108 (T31-7). T28 (P2-16), and T35 (P31-29) show multiple insertions of the transgene. $B g l I$ does not cut the DNA construct used to generate the transgene in papaya plants. No bands were seen in the lane with the DNA from a nontransformed papaya plant (NT).

observed from this type of tissue. The rationale of this method is similar to that reported by Cabrera-Ponce et al. (1995) who visually selected young embryos before bombardment. However, our method eliminates the use of visual selection which can be laborious. Another advantage is that fewer embryos are needed for each experiment; thus, more experiments can be done. However, this could also be a disadvantage since the transformation results in each experiment are dependent on the integrity of fewer embryos. This is the first report of spreading papaya somatic embryos on filter paper in order to regulate the age of the explant and induce rapid cell growth.

A second key element was to remove the bombarded kanamycinresistant clusters from all kanamycin selection as soon as the clusters had grown to $2-3 \mathrm{~cm}$ in diameter. Our cultures were transferred to kanamycin selection (75 mg/L) $7 \mathrm{~d}$ after bombardment. After a mo., this level was raised to $150 \mathrm{mg} / \mathrm{L}$. However, after resistant embryo clusters attained $2-3 \mathrm{~cm}$ in diameter, they were removed to media without kanamycin. Fitch et al. (1990) did not commence kanamycin selection at $75 \mathrm{mg} / \mathrm{L}$ until 3 to $5 \mathrm{mo}$. after bombardment. They raised the kanamycin level to $150 \mathrm{mg} / \mathrm{L}$ a mo. later and apparently maintained this level through the germination phase. Reports have shown that kanamycin can be harmful to transgenic plant growth, even when the plants have the kanamycin resistance (NPTII) gene (Gray and Meredith, 1992; Yepes and Aldwinckle, 1994). With papaya, Mahon et al. (1996) observed a slow growth rate of embryos after 5 mo. on kanamycin at levels of $150-300 \mu \mathrm{g} / \mathrm{ml}$. After subsequent reduction of kanamycin to $25 \mu \mathrm{g} / \mathrm{ml}$, the growth of these embryos did not approach the growth rate of controls on nonselective medium. A pos- 
sible disadvantage is that once the embryogenic cluster is removed from selection, any existing nontransgenic cells might be encouraged to grow and overtake the transgenic cluster. However, this was clearly not observed in our experiments.

A third element was the stage at which embryos were transferred from induction to maturation medium. The transfer of embryo clusters with finger-like extensions to maturation medium almost always guaranteed that the embryos would germinate after they were placed on germination medium. This was a critical step because most of the embryos were kept on maturation medium for only $2-3 \mathrm{wk}$ and then were automatically transferred to germination medium.

The fourth element for improving the transformation protocol was to simplify the rooting procedure. Plantlets were allowed to remain in germination medium until they formed root initials, were 0.5 to $1.0 \mathrm{~cm}$ tall, and had at least two green true leaves. Plantlets were then transferred to root development medium consisting of vermiculite infused with an equal volume of liquid rooting medium. Many branchy roots were produced and rooting was virtually guaranteed, ensuring the timeliness of plant transfer to the greenhouse.

Kanamycin-resistant embryo clusters developed in selective induction medium from 3 to 9 mo. after bombardment (Table 1). However, $84 \%(70 / 83)$ of these clusters were identified as transgenic lines by the fourth mo. after bombardment. Our data are similar to those of other reports, which show that 4 mo. might be the optimal time for selection of kanamycin-resistant embryogenic clusters. Other researchers have reported similar optimal time frames. Fitch et al. (1990) reported selecting 7 of a total of 15 putative transformed lines by the fourth mo. after bombardment. Also, Cabrera-Ponce et al. (1995) and Mahon et al. (1996) selected transformed embryos for 3.5 to 5 mo., and for 3 to 5 mo., respectively.

A routine practice in our laboratory is to maintain back-up cultures in induction and germination media until a stock plant of each plant line is well established in the greenhouse. This can be easily done with our protocol because initial kanamycin-resistant clusters are subsequently multiplied in kanamycin-free medium which results in many plates of cultures from each line. This practice was especially useful when lines were lost to contamination after the induction step. Likewise, back-up cultures in germination medium ensured a steady supply of plantlets that could be used. if needed. There are potential disadvantages, however. First, prolonged exposure to 2,4-D increases the chances of developing abnormal plants. Second, since the clusters are subsequently multiplied, it is possible that independent lines might arise from the same cluster. In this study, PCR and Southern blot analyses were done on a small population of plants to verify that the transgene is stable in plants and to obtain preliminary data on the number of gene copies in these lines. Ultimately, careful molecular and genetic analysis of each line is needed to differentiate plants coming from each transgenic cluster.

Direct comparisons of transformation efficiency for papaya are not easily made, due to nonstandardized methods of accounting among the different studies and to differences in the developmental stage of the transgenic material used (from calluses in tissue culture to plants established in the greenhouse) as the basis for calculating efficiency. For example, in our study, we obtained $100 \%$ transformation of bombarded plates of freshly spread embryos, which eventually resulted in transgenic lines from all plates. On the other hand. in Australia, Mahon et al. (1996) reported an average transformation rate of $41 \%$ of their bombarded plates. It is difficult to compare these results because Mahon et al. used secondary embryos of a dioecious
Australian papaya cultivar, and their rate of transformation was based only on the number of transformed clones and not on the number of transformed plant lines.

Thus, to compare our transformation efficiency of embryogenic tissues with that of Fitch et al. $(1990,1992)$ we used the number of independent transgenic clusters (or "isolates") produced from a gram fresh weight $(\mathrm{FW})$ of bombarded embryogenic tissues. Whereas we obtained 55 transgenic isolates/g FW of somatic embryos, Fitch et al. (1990) reported 0.26 transgenic isolates/g FW of embryogenic tissues ( 5 isolates were obtained from $19 \mathrm{~g} \mathrm{FW}$ ). Although in a later study, this figure was revised upwards to 1.14 transgenic isolates/g FW (Fitch et al.. 1992), the efficiency rate was very low. Also, of the five lines that regenerated plants from embryogenic tissues, only two were reported to be normal (Fitch et al., 1992). In contrast, we report here that 83 transgenic papaya plant lines were regenerated from only $1.5 \mathrm{~g}$ of embryogenic tissues and were successfully transferred to the greenhouse. In another study, Cabrera-Ponce et al. (1995) obtained 60 transgenic lines/g FW of bombarded embryogenic material. Rather than spreading these tissues to establish uniform cell growth, embryos at the globular, heart, and early torpedo stages were carefully selected and transferred to plates for bombardment.

We believe that it is useful to determine transformation efficiency based on the number of transgenic plant lines that can be established in the greenhouse, and not on tissues or plantlets that are still in different phases of tissue culture. But often, this information is not available in published reports. Using this criterion, we obtained $100 \%$ transformation efficiency of 'Sunrise' papaya based on the percentage of bombarded plates that produced transgenic plants. In a study done in Mexico, Cabrera-Ponce et al. (1995) also attained $100 \%$ efficiency of transgenic plants. These were produced by bombarding somatic embryos of 'Maradol' papaya that were cultured from zygotic embryos.

We also measured transformation efficiency based on the number of transgenic plant lines obtained per number of embryo clusters used for spreading ( 1.3 per cluster). These rates cannot be directly compared with those of other studies because corresponding data were not given for transgenic plants that were established in the greenhouse.

The initial goals of this research were to transform 'Sunrise' papaya with the untranslatable CP gene of PRSV HA and to compare its resistance to that of the "Sunset" transgenic papaya line 55-1 that had been previously developed with the translatable CP gene of PRSV HA 5-1 (Ling et al., 1991; Fitch et al., 1992: Tennant et al., 1994), which is a mild mutant of PRSV HA (Yeh and Gonsalves, 1984). In particular we wanted to determine if RNA-mediated protection (Lomonossoff, 1995) would be operational for PRSV, and if we would still have the same narrow resistance we observed for hemizygous plants of line 55-1 (Tennant et al., 1994). Recently, Tennant et al. $(1996,1997)$ showed that plants of Line 55-1 that were homozygous for the CP transgene were resistant to a larger number of isolates than the hemizygous plants. Similar evidence was found in an independent report by Yeh et al. (1997) who showed that transgenic papaya expressing the CP gene of a PRSV strain from Taiwan were resistant to a range of PRSV isolates. These observations suggest that PRSV could possibly be controlled worldwide with cultivars expressing CP genes from a few PRSV strains.

Ongoing infectivity studies using the transgenic papaya lines developed in this work have shown that a number of Ro transgenic plants are highly resistant to PRSV isolates from Hawaii and some 
of them show high resistance to PRSV strains from Australia, Mexico, Jamaica, and Brazil (Gonsalves et al., 1997).

\section{ACKNOWLEDGMENTS}

We thank Richard Manshardt and Francis Zee for 'Sunrise' papaya fruit; Mary Horner and Nan Lu for tissue culture assistance and Sheri Day for greenhouse assistance.

\section{REFERENCES}

Arriola, M. D.; Calzada, J.; Menchu, J.; Rolz, C.; Garcia, R.; Cabrera, S. D. Papaya. In: Nagy, S.; Shaw, P., ed. Tropical and subtropical fruits. Westport: AVI; 1980:316-340.

Ausubel, F. M.; Brent, R.; Kingston, R. E.; Moore, D. D.; Seidman, J. G.; Smith, J. A.; Struhl, K., ed. Current protocols in molecular biology. New York: John Wiley and Sons, Inc.; 1995:2.9.1-2.9.20.

Cabrera-Ponce, J. L.; Vegas-Garcia, A.; Herrera-Estrella, L. Herbicide resistant transgenic papaya plants produced by an efficient particle bombardment transformation method. Plant Cell Rep. 15:1-7; 1995.

Cheng, Y.-H.; Yang, J.-S.; Yeh, S.-D. Efficient transformation of papaya by coat protein gene of papaya ringspot vinus mediated by Agrobacterium following liquid-phase wounding of embryogenic tissues with carborundum. Plant Cell Rep. 16:127-132; 1996.

Ferreira, S. A.; Pitz, K. Y.; Manshardt, R.; Zee, F.; Fitch, M.; Gonsalves, D. Transgenic papaya controls papaya ringspot virus in Hawaii. Phytopathology 87:S30 (Abstr.); 1997.

Fitch, M. M. M.; Manshardt, R. M.; Gonsalves, D.; Slightom, J. L.; Sanford, J. C. Stable transformation of papaya via microprojectile bombardment. Plant Cell Rep. 9:189-194: 1990.

Fitch, M. M. M.; Manshardt, R. M.; Gonsalves, D.; Slightom, J. L.; Sanford, J. C. Virus resistant papaya plants derived from tissues bombarded with the coat protein gene of papaya ringspot virus. Bio/Technology 10:1466-1472; 1992.

Fitch, M. M. M. High frequency somatic embryogenesis and plant regeneration from papaya hypocotyl callus. Plant Cell Tissue Organ Cult. 32:205-212; 1993

Fuente, J. M.; Ramirez-Rodriguez, V.; Cabrera-Ponce, J. L.; Herrera-Estrella, L. Aluminum tolerance in transgenic plants by alteration of citrate synthesis. Science 276:1566-1568; 1997.

Galinsky, R. World market for papaya. Regional Agribusiness Project Market Information Bulletin. USAID-Asia RAP. Feb., No. 12. Online. Internet. $1996: 5$ p.

Gonsalves, D. Papaya ringspot virus. In; Ploetz, R. C.; Zentmyer, G. A.; Nishijima, W. T.; Rohrbach, K. G,; Ohr, H. D., ed. Compendium of tropical fruit diseases. St. Paul: APS Press; 1994:67-68.

Gonsalves, D. Control of papaya ringspot virus in papaya: a case study. Annu. Rev. Phytopathol, 36:415-437; 1998.

Gonsalves, C.; Cai, W.; Tennant, P.; Gonsalves, D. Efficient production of virus resistant transgenic papaya plants containing the untranslatable coat protein gene of papaya ringspot virus. Phytopathology 87:S34 (Abstr.); 1997.

Gonsalves, D.; Ishii, I. Purification and serology of papaya ringspot virus. Phytopathology 70:1028-1032; 1980.

Gray, D. J.; Meredith, C. P. Grape. In: Hammerschlag, F. A.; Litz, R. E., ed. Biotechnology of perennial fruit crops. Wallingford, Oxford, UK: CAB International; 1992:229-262.

Jefferson, R. A. Assaying chimeric genes in plants: the GUS gene fusion system. Plant Mol. Biol. Rep. 5:387-405; 1987.

Ling, K.; Namba, S.; Gonsalves, C.; Slightom, J. L.; Gonsalves, D. Protection against detrimental effects of potyvirus infection in transgenic tobacco plants expressing the papaya ringspot virus coat protein gene. Biof Technology 9:752-758; 1991 .

Lius, S.; Manshardt, R. M.; Fitch, M. M. M.; Slightom, J. L.; Sanford, J. C.; Gonsalves, D. Pathogen-derived resistance provides papaya with effective protection against papaya ringspot virus. Mol. Breed. 3:161168; 1997.

Lomonossoff, G. P. Pathogen-derived resistance to plant viruses. Annu. Rev. Phytopathol. 33:323-343; 1995.
Mahon, R. E.; Bateson, M. F.; Chamberlain, D. A.; Higgins, C. M.; Drew, R. A.; Dale, J. L. Transformation of an Australian variety of Carica papaya using microprojectile bombardment. Aust. J. Plant Physiol. 23:679-685; 1996 .

Manshardt, R. M. 'UH Rainbow' papaya. Univ. Hawaii Coll. Trop. Agric. Human Res. Germplasm G-1. Honolulu: University of Hawaii; 1998:2 $\mathrm{p}$.

Manshardt, R. M.; Wenslaff, T. F. Interspecific hybridization of papaya with other Carica species. J. Am. Soc. Hortic. Sci. 114:689-694; 1989.

McCabe, D. E.; Swain, W. F.; Martinell, B. J.; Christou, P. Stable transformation of soybean (Glycine max) by particle acceleration. Bio/Technology 6:923-926; 1988.

Murashige, T; Skoog, F. A revised medium for rapid growth and bioassay with tobacco tissue cultures. Physiol. Plant. 15:473-497; 1962.

Purcifull, D.; Edwardson, J.; Hiebert, E.; Gonsalves, D. Papaya ringspot virus. CMI/AAB Descriptions of plant viruses, No. 292. (No. 84 Revis., July 1984). 1984:8 p.

Quemada, H.; L'Hostis, B.; Gonsalves, D.; Reardon, I. M.; Heinrikson, R.; Hiebert, E. L.; Sieu, L. C.; Slightom, J. L. The nucleotide sequences of the 3 -terminal regions of papaya ringspot virus strains $W$ and $P$. J. Gen. Virol. 71:203-210: 1990.

Razin, A. Assays for studying DNA methylation. In: Gelvin, S. B.; Schilperoort, R. A.; Verma, D. P. S., ed. Molecular biology manual. Dordrecht, The Netherlands: Kluwer Academic Publishers; 1988:B3:1-28.

Sanford, J. C.; Johnston, S. A. The concept of parasite-derived resistancederiving resistance genes from the parasite's own genome. J. Theor. Biol. 113:395-405; 1985.

Sanford, J. C.; Smith, F. D.; Russell, J. A., ed. Optimizing the biolistic process for different biological applications. Methods Enzymol. 217:483-509; 1992.

Shukla, D. D.; Ward, C. W.; Brunt, A. A. The Potyviridae. Wallingford, UK: CAB International; 1994:516 p.

Slightom, J. L. Custom polymerase-chain-reaction engineering of a plant expression vector. Gene 100:251-256; 1991.

Tennant, P. F. Evaluation of the resistance of coat protein transgenic papaya against papaya ringspot virus isolates and development of transgenic papaya for Jamaica. Ph.D. thesis. Ithaca: Cornell University; 1996:317P

Tennant. P.; Fitch, M.; Manshardt, R.; Slightom, J.; Gonsalves, D. Resistance against papaya ringspot virus isolates in coat protein transgenic papaya is affected by transgene dosage and plant development. Phytopathology 87:S96 (Abstr.); 199?.

Tennant. P. F.; Gonsalves, C.; Ling, K.-S.; Fiteh, M.; Manshardt, R.; Slightom, J. L.; Gonsalves, D. Differential protection against papaya ringspot virus isolates in coat protein gene transgenic papaya and classically cross-protected papaya. Phytopathology 84:1359-1366; 1994.

Yang, J.-S.; Yu, T.-A.; Cheng, Y.-H.; Yeh, S.-D. Transgenic papaya plants from Agrobacterium-mediated transformation of petioles of in vitro propagated multishoots. Plant Cell Rep. 15:459-464; 1996.

Yeh, S.-D.; Cheng, Y.-H.; Bau, H.-J.; Yu, T.-A.; Yang, J.-S. Coat-protein transgenic papaya immune or highly resistant to different strains of papaya ringspot potyvirus. Phytopathology 87:S107 (Abstr.); 1997.

Yeh, S.-D.; Gonsalves, D. Evaluation of induced mutants of papaya ringspot virus for control by cross protection. Phytopathology 74:1086-1091; 1984.

Yeh, S.-D.; Gonsalves, D. Practices and perspective of control of papaya ringspot virus by cross protection. In: Harris, K. F., ed. Advances in disease vector research. New York: Springer-Verlag; 1994:237-257.

Yeh, S.-D.; Jan, F.-J.; Chiang, C.-H.; Doong, P.-J.; Chen, M.-C.; Chung, P.H.; Bau, H.-J. Complete nucleotide sequence and genetic organization of papaya ringspot virus RNA. J. Gen. Virol, 73:2531-2541; 1992.

Yepes, L. M.; Aldwinckle, H. S. Factors that affect leaf regeneration efficiency in apple, and effect of antibiotics in morphogenesis. Plant Cell Tissue Organ Cult. 37:257-269; 1994.

Yepes, L. M.; Fuchs, M.; Slightom, J. L.; Gonsalves, D. Sense and antisense coat protein gene constructs confer high levels of resistance to tomato ringspot nepovirus in transgenic Nicotiana species. Phytopathology 86:417-424; 1996. 